REVIEW

\title{
Genetics of skin appendage neoplasms and related syndromes
}

\author{
D A Lee, M E Grossman, P Schneiderman, J T Celebi
}

J Med Genet 2005;42:81 1-819. doi: 10.1136/jmg.2004.025577

In the past decade the molecular basis of many inherited syndromes has been unravelled. This article reviews the clinical and genetic aspects of inherited syndromes that are characterised by skin appendage neoplasms, including Cowden syndrome, Birt-Hogg-Dube syndrome, naevoid basal cell carcinoma syndrome, generalised basaloid follicular hamartoma syndrome, Bazex syndrome, BrookeSpiegler syndrome, familial cylindromatosis, multiple familial trichoepitheliomas, and Muir-Torre syndrome.

See end of article for authors' affiliations .......................

Correspondence to: Dr Julide Tok Celebi, Department of

Dermatology, Columbia University, 630 West

168th Street, VC-15-202,

New York, NY 10032,

USA; j†165@columbia.edu

Received 7December 2004

Revised version received

2 February 2005

Accepted for publication

15 February 2005
S kin consists of both epidermal and dermal components. The epidermis is a stratified squamous epithelium that rests on top of a basement membrane, which separates it and its appendages from the underlying mesenchymally derived dermis. Epidermal stem cells give rise to the epidermis and its appendages in the skin. ${ }^{1}$ Skin appendages include hair follicles, sebaceous glands, and eccrine and apocrine sweat glands. Skin appendage tumours are a large and diverse group that are classified according to their level of appendageal differentiation as follicular, sebaceous, eccrine, or apocrine.

Skin appendage neoplasms present as papules ("bumps") on the skin that are difficult to distinguish clinically from one another. They can be solitary or multiple. They are typically multiple when they are associated with an inherited syndrome. The most common presentation is facial papules. Although these papules can cover the entire face, they cluster on the central facial areas of the nose, nasolabial folds, upper lip, and forehead. The gold standard in diagnosis is histopathological examination of a skin biopsy. Even then some cases may still be difficult to classify.

In this review we focus on neoplasms of the skin appendages associated with inherited syndromes, most of which are family cancer syndromes (table 1). In all of these genodermatoses, the cutaneous tumours represent the pathognomonic finding of the disease. Thus the recognition of these disorders early, through careful skin examination, may lead to life saving cancer screening in these patients and their family members.

\section{COWDEN SYNDROME}

Cowden syndrome (OMIM 158350) is an autosomal dominantly inherited disease, first described in 1962, characterised by mucocutaneous lesions and benign and malignant tumours in various organ systems such as the breast, thyroid, and endometrium. ${ }^{2}$

\section{Clinical features of Cowden syndrome}

The cutaneous findings of Cowden syndrome include trichilemmomas, oral papillomas, and acral and palmoplantar keratoses. The cutaneous hallmark of the disease is multiple trichilemmomas which present clinically as rough hyperkeratotic papules typically localised on the face (nasolabial folds, nose, upper lip, forehead, ears ${ }^{3}$ (fig 1A, 1C, 1D). Trichilemmomas are benign skin appendage tumours or hamartomas that show differentiation towards the hair follicles (specifically for the infundibulum of the hair follicle). ${ }^{4}$ Oral papillomas clinically give the lips, gingiva, and tongue a "cobblestone" appearance and histopathologically show features of fibroma. ${ }^{3}$ The mucocutaneous manifestations of Cowden syndrome usually present in the second decade and are seen in 99\% of affected individuals. ${ }^{5}$ The International Cowden Consortium established criteria for the diagnosis of Cowden syndrome. $^{5}$

Cowden syndrome patients are predisposed to benign and malignant tumours of various organs. In 1978, Brownstein et al first noted the association of Cowden syndrome with breast carcinoma. ${ }^{6}$ The lifetime risk for breast cancer in Cowden syndrome is estimated to be $25-50 \%$. $^{36}$ As in the general population, ductal carcinomas are the most commonly observed malignant lesion in Cowden syndrome. Benign breast disease-in the form of fibroadenomas, apocrine metaplasia, microcysts, adenosis, and mammary hamartoma-like lesions-is usually bilateral and extensive at an early age in Cowden syndrome. ${ }^{7}$ The risk for thyroid cancer (typically follicular) is approximately $10 \%$, while the risk for endometrial cancer is estimated to be $5-10 \% .^{5}$

Lhermitte-Duclos disease, or dysplastic gangliocytoma of the cerebellum, is a hamartomatous growth and has been shown to be a component of Cowden syndrome. ${ }^{89}$ Clinically, it manifests with increased intracranial pressure, ataxia, and seizures. Although familial cases are well characterised, it is typically sporadic.

Abbreviations: BCC, basal cell carcinoma; BHDS, BirtHogg-Dube syndrome; BRRS, Bannayan-RileyRuvalcaba syndrome; BSS, Brooke-Spiegler syndrome; FC, familial cylindromatosis; GBFHS, generalised basaloid follicular hamartoma syndrome; MFT, multiple familial trichoepithelioma; MTS, Muir-Torre syndrome; NBCCS, naevoid basal cell carcinoma syndrome 
Table 1 Tumour phenotypes, loci and genes in inherited syndromes associated with skin appendage neoplasms

\begin{tabular}{|c|c|c|c|c|c|c|}
\hline Disorder & $\begin{array}{l}\text { OMIM } \\
\text { number }\end{array}$ & Inheritance & Skin tumour phenotype & $\begin{array}{l}\text { Most common internal } \\
\text { malignancy }\end{array}$ & Locus & Gene symbol/gene name \\
\hline Cowden syndrome & 158350 & $A D$ & Trichilemmoma & $\begin{array}{l}\text { Breast } \mathrm{Ca} \\
\text { Thyroid } \mathrm{Ca} \\
\text { Endometrial } \mathrm{Ca}\end{array}$ & $10 q 23.3$ & $\begin{array}{l}\text { PTEN } \\
\text { Phosphatase and tensin } \\
\text { homolog }\end{array}$ \\
\hline $\begin{array}{l}\text { Birt-Hogg-Dube } \\
\text { syndrome }\end{array}$ & 135150 & $A D$ & $\begin{array}{l}\text { Fibrofolliculoma } \\
\text { Trichodiscoma }\end{array}$ & $\begin{array}{l}\text { Renal cell Ca } \\
\text { Colon Ca?* }\end{array}$ & $17 p 11.2$ & $\begin{array}{l}\text { FLCN } \\
\text { Folliculin }\end{array}$ \\
\hline $\begin{array}{l}\text { Naevoid basal cell } \\
\text { carcinoma syndrome }\end{array}$ & 109400 & $A D$ & Basal cell carcinoma & Medulloblastoma & $9 q 22.3$ & $\begin{array}{l}\text { PTCH } \\
\text { Patched homolog } \\
\text { (Drosophila) }\end{array}$ \\
\hline $\begin{array}{l}\text { Generalised basaloid } \\
\text { follicular hamartoma } \\
\text { syndrome }\end{array}$ & 605827 & $A D$ & $\begin{array}{l}\text { Basaloid follicular } \\
\text { hamartoma }\end{array}$ & $\begin{array}{l}\text { No significant association } \\
\text { identified }\end{array}$ & Not identified & Not identified \\
\hline Bazex syndrome & 301845 & $\mathrm{XLD}$ & Basal cell carcinoma & $\begin{array}{l}\text { No significant association } \\
\text { identified }\end{array}$ & Not identified & Not identified \\
\hline $\begin{array}{l}\text { Brooke-Spiegler } \\
\text { syndrome }\end{array}$ & 605041 & $A D$ & $\begin{array}{l}\text { Cylindroma } \\
\text { Trichoepithelioma } \\
\text { Spiradenoma }\end{array}$ & Parotid adenoca & $16 q 12-q 13$ & $\begin{array}{l}\text { CYLD } \\
\text { Cylindromatosis }\end{array}$ \\
\hline Familial cylindromatosis & 132700 & $A D$ & Cylindroma & Parotid adenoca & $16 q 12-q 13$ & $\begin{array}{l}\text { CYLD } \\
\text { Cylindromatosis }\end{array}$ \\
\hline $\begin{array}{l}\text { Multiple familial } \\
\text { trichoepithelioma }\end{array}$ & 601606 & $A D$ & Trichoepithelioma & $\begin{array}{l}\text { No significant association } \\
\text { identified }\end{array}$ & $\begin{array}{l}9 p 21 \\
16 q 12-q 13\end{array}$ & $\begin{array}{l}\text { Not identified } \\
\text { CYLD } \\
\text { Cylindromatosis }\end{array}$ \\
\hline Muir-Torre syndrome & 158320 & $A D$ & $\begin{array}{l}\text { Sebaceous adenoma } \\
\text { Sebaceous epithelioma } \\
\text { Sebaceous carcinoma } \\
\text { Keratoacanthoma }\end{array}$ & $\begin{array}{l}\text { Colon } \mathrm{Ca} \\
\text { Genitourinary } \mathrm{Ca}\end{array}$ & $3 p 21.3$ & $\begin{array}{l}\text { MSH2 } \\
\text { MutShomolog 2, colon } \\
\text { cancer, non-polyposis type } 1 \\
\text { (E coli) } \\
\text { MLH1 } \\
\text { MutLhomolog 1, colon } \\
\text { cancer, non-polyposis type } 2 \\
\text { (E coli) }\end{array}$ \\
\hline
\end{tabular}

*The association of BHDS and colon carcinoma remains controversial.

$A D$, autosomal dominant; adenoca, adenocarcinoma; Ca, carcinoma; XLD, $X$ linked dominant.

\section{Genetics of Cowden syndrome}

The susceptibility gene for Cowden syndrome was mapped to $10 q 22-23 .{ }^{10}$ Subsequently, germline mutations in a candidate tumour suppressor gene within this region, PTEN/MMACl/ TEPl, was identified in families with Cowden syndrome. ${ }^{11-13}$ The PTEN gene consists of nine exons and encodes a 403 amino acid protein. PTEN is a tumour suppressor in vitro and in vivo. It is a dual specificity phosphatase that dephosphorylates both protein and lipid substrates. PTEN is a negative regulator of the PI3K/AKT signalling pathway that is required for cell survival and proliferation. PTEN expression leads to downregulation of AKT activation and increased apoptosis. ${ }^{14}$ In addition, PTEN regulates and inhibits the mitogen activated kinase pathway. Studies also suggest a role for PTEN in insulin signalling by inhibiting the insulin stimulation of the mitogen activated kinase pathway. ${ }^{14}$

Using the International Cowden Consortium operational criteria for the diagnosis of Cowden syndrome, germline PTEN mutations are identified in Cowden syndrome families with a frequency of $81 \% .{ }^{15}$ Exon 5 of PTEN, which encodes the core motif, is a hotspot for mutations and accounts for $40 \%$ of all Cowden syndrome germline mutations. ${ }^{15}$ Studies evaluating genotype-phenotype correlation show that germline PTEN mutations are associated with malignant breast disease. Mutations within the core motif in exon 5 appear to be associated with involvement of five or more organs, a surrogate phenotype for severity for disease. ${ }^{15}$

Interestingly, mutations of PTEN have been documented in other disorders. Bannayan-Riley-Ruvalcaba syndrome
(BRRS) (OMIM 153480) is an autosomal dominantly inherited disorder characterised by macrocephaly, developmental delay, lipomatosis, vascular malformations, and pigmented macules of the glans penis, and has a PTEN mutation frequency of $50-60 \%{ }^{16}$ Although, Cowden syndrome and BRRS are phenotypically distinct, there are Cowden syndrome/BRRS overlap families where some members present with Cowden syndrome and others with BRRS; these are associated with a single germline PTEN mutation, suggesting that they are allelic. ${ }^{17}$ Although patients with BRRS were not originally considered to have increased risk for cancer, the identification of germline PTEN mutations in over $50 \%$ of these patients suggests a risk for cancers related to Cowden syndrome. ${ }^{5}$

Similarly, germline PTEN mutations have also been observed in proteus syndrome (OMIM 176920) and proteus-like syndrome. ${ }^{18}$ Proteus syndrome is characterised by the presence of partial gigantism of the hands or feet or both, pigmented nevi, hemihypertrophy, macrocephaly, and subcutaneous hamartomatous tumours. ${ }^{18}$ Germline PTEN mutations have been found in approximately $20 \%$ of patients with the classic proteus syndrome, and a mutation frequency of $60 \%$ was observed in individuals with proteus-like features. ${ }^{18}$ Therefore, a subgroup of cases of proteus syndrome appears to be allelic with Cowden syndrome and BRRS. As a result, it has been proposed that these syndromes that are defined by germline PTEN mutations should collectively be termed PTEN hamartoma tumour syndrome. ${ }^{5}$ In addition, PTEN mutations have been found in several patients with 


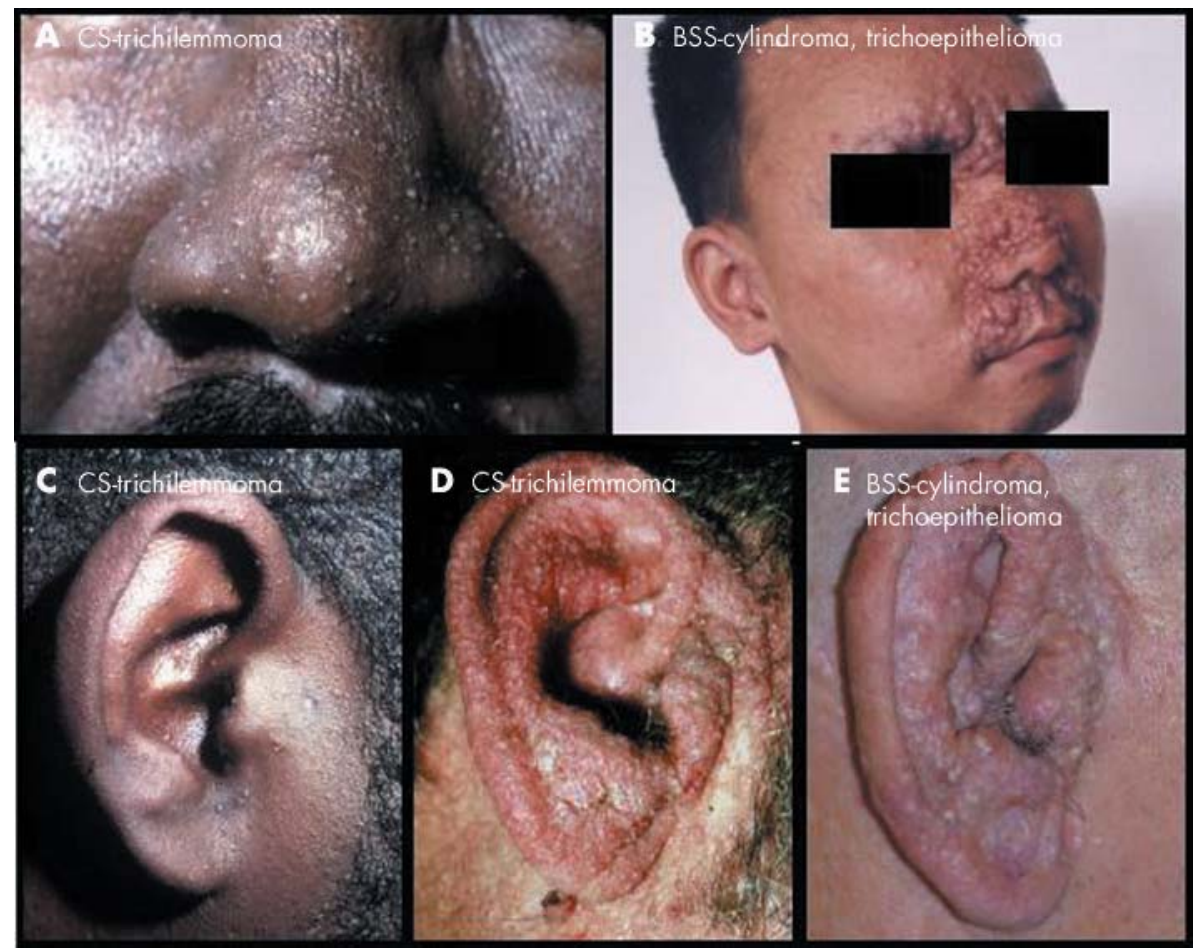

Figure 1 Clinical findings in Cowden syndrome and Brooke-Spiegler syndrome (BSS). Facial papules ("bumps") predominantly located on the nose, nasolabial folds, and upper lip. Histopathology shows (A) trichilemmomas; (B) trichoepitheliomas and cylindromas. Facial papules located on the ears: (C) and (D), trichilemmomas; (E) trichoepitheliomas and cylindromas. Note that the trichilemmomas seen in Cowden syndrome and the trichoepitheliomas and cylindromas seen in BSS are clinically indistinguishable. The written consent of the patients for publication of these photographs was obtained.

macrocephaly and autistic features. ${ }^{5}$ A child with VATER association (vertebral and anal malformations, tracheooesophageal atresia, and radial and renal malformations) and macrocephaly with a germline PTEN mutation has been reported. ${ }^{5}$ The association of PTEN and these disorders has yet to be determined.

\section{BIRT-HOGG-DUBE SYNDROME}

Birt-Hogg-Dube syndrome (BHDS) (OMIM 135150) is an autosomal dominantly inherited disorder first described in 1977, characterised by follicular hamartomas (fibrofolliculoma and trichodiscoma) and a predisposition to renal tumours and pulmonary disease. ${ }^{19}$

\section{Clinical features of BHDS}

Clinically, fibrofolliculomas and trichodiscomas are 2 to 4 $\mathrm{mm}$, smooth, dome shaped yellow-white papules often seen on the face (nasolabial folds, nose, upper lip, forehead, ear) and upper trunk (fig 2C, 2D). It is difficult to distinguish these lesions clinically and histopathologically. Fibrofolliculomas and trichodiscomas are benign skin appendage tumours/hamartomas that show differentiation toward hair follicles (specifically, fibrofolliculomas towards the mantle of the hair follicle, and trichodiscomas towards the mesodermal components of the hair discs). ${ }^{19-21}$ There have been no reports of malignant transformation of either lesion. Acrochordons (skin tags), originally described as a part of the syndrome, is a non-specific cutaneous finding observed in BHDS. ${ }^{22}$ Cutaneous lesions in BHDS usually appear in the third or fourth decades of life.

Roth et al described the first case of renal cell carcinoma associated with BHDS ${ }^{23}$ and subsequent studies have shown a histopathological spectrum of tumours including oncocytoma and chromophobe, papillary, and clear cell renal carcinomas that segregate together with BHDS in an autosomal dominant fashion..$^{24}$ Similarly, spontaneous pneumothoraces, pulmonary cysts, and bullous emphysema have consistently been observed in BHDS patients. ${ }^{24}$ Less frequently associated lesions include medullary carcinoma of the thyroid, ${ }^{19}$ multiple lipomas and angiolipomas, ${ }^{25}$ parotid oncocytoma, ${ }^{26}$ and neural tissue tumours. ${ }^{27}$ The association of colorectal neoplasms and BHDS remains controversial. A recent clinical study showed the absence of colorectal neoplasia in 152 patients from 49 families. ${ }^{28}$ Another study failed to show an increased risk for colon polyps and colon cancer in BHDS families. ${ }^{24}$ By contrast, evaluation of some BHDS families suggested a predisposition for colon cancers. ${ }^{29}$ Although, an association between BHDS and colorectal cancer is controversial, recent studies suggest a role for the BHDS gene in sporadic colorectal cancers with or without microsatellite instability. ${ }^{30} 31$

\section{Genetics of BHDS}

Two independent groups mapped the susceptibility gene to $17 \mathrm{p} 11.2^{32}$ and to $17 \mathrm{pl}-\mathrm{q} 11.2$, $^{33}$ respectively, by using genome-wide linkage analysis. Subsequently, a novel gene named folliculin was identified and germline mutations were found in families with BHDS. ${ }^{34}$ The gene has 14 coding exons and encodes a protein of 579 amino acids. ${ }^{34}$ Based on the detection of loss of heterozygosity ( $\mathrm{LOH})$ in BHDS related tumours, folliculin is considered to be a putative tumour suppressor. Interestingly, some studies of sporadic and familial BHDS cases suggested somatic mutation instead of loss of heterozygosity as the second hit in Knudson's two hit theory in BHDS tumours. ${ }^{29}$ To date, the function of folliculin remains unknown. The majority of mutations $(\sim 40-50 \%)$ in BHDS involve a poly $(\mathrm{C})_{8}$ tract (nt 1733-1740) in exon 11 and thus this repeat tract represents a BHDS mutational hot spot. $^{29}$ 


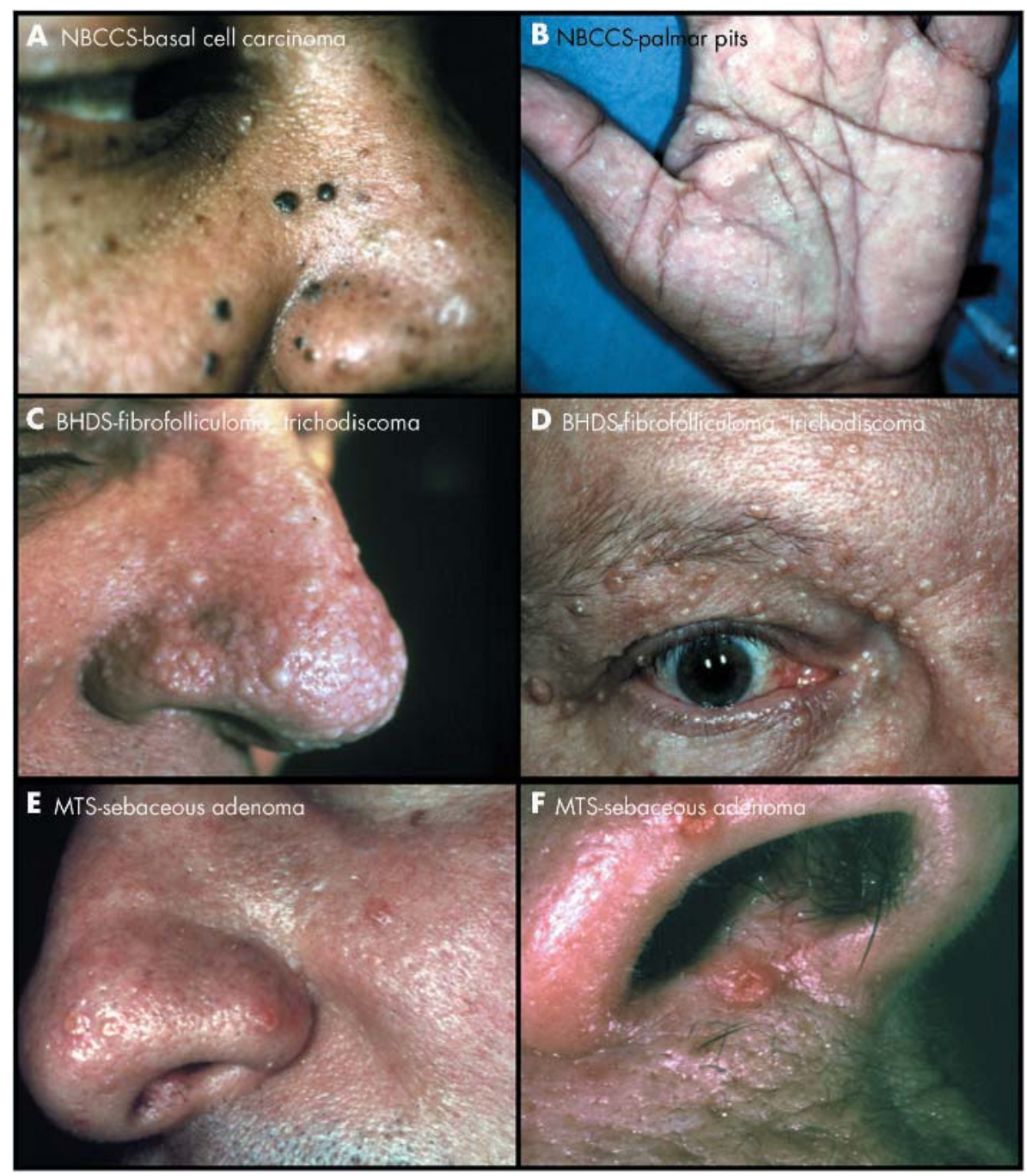

Figure 2 Clinical findings in naevoid basal cell carcinoma syndrome (NBCCS), generalised basaloid follicular hamartoma syndrome (GBFHS), BirtHogg-Dube syndrome (BHDS), and Muir-Torre syndrome (MTS). (A) 2-3 mm black papules on the face show histopathological features of basal cell carcinoma in a patient with NBCCS; (B) prominent palmar pits after soaking in water in a patient with NBCCS; (C) and (D) fibrofolliculomas and trichodiscomas in BHDS; (E) and (F) sebaceous adenomas in MTS. Note that the skin appendage tumours seen in these inherited syndromes cannot be distinguished on the basis of clinical examination. The written consent of the patients for publication of these photographs was obtained.

\section{NAEVOID BASAL CELL CARCINOMA SYNDROME}

Naevoid basal cell carcinoma syndrome (NBCCS) (OMIM 109400), also referred to as Gorlin syndrome or Gorlin-Goltz syndrome, is an autosomal dominantly inherited disorder first described in 1960, characterised by developmental anomalies and early onset neoplasms. ${ }^{35}$ Basal cell carcinoma (BCC) of the skin is the most common neoplasm in this disorder.

\section{Clinical features of NBCCS}

The characteristic cutaneous marker of NBCCS is BCCs numbering from a few to several thousand, primarily localised on the face, neck, and upper trunk (fig $2 \mathrm{~A}$ ). ${ }^{36}$ BCC is the most common cancer in humans. Although most cases occur sporadically, $0.5 \%$ of BCC cases are attributable to NBCCS ${ }^{37}$ The BCCs in NBCCS- unlike sporadic BCCs that occur outside the syndrome-appear much earlier in life, usually arising between puberty and age $35 .{ }^{36}$ In prepubescent patients, BCCs are innocuous in appearance even when numbering in the thousands. Aggressive behaviour and local invasion are observed only after adolescence. ${ }^{36}$ In rare instances, local invasion of the bone and brain resulting in death can occur. ${ }^{38}$ Metastases to the lungs and other internal organs are also rare. ${ }^{39} 40$ Other cutaneous findings in NBCCS include the presence of small asymmetrical palmar or plantar pits, or both, which become readily visible after soaking the hands or feet in water for a few minutes (fig $2 \mathrm{~B}$ ). There have been reports describing BCCs arising in the base of these pits. $^{41}$

Odontogenic keratocysts of the jaw represent a classic finding of this syndrome. ${ }^{35}$ Unlike the more commonly observed isolated cases, odontogenic keratocysts associated with NBCCS arise a decade earlier, appearing around the age of seven and peaking during the second or third decades. These cysts occur more often in the mandible than the maxilla and present as large, asymmetrical, loculated bilateral lesions which typically recur after removal. Rarely they give rise to squamous cell carcinoma, resulting in pathological fracture or limited expansion of the jaws. ${ }^{42}$

There are several abnormalities of the skeletal system associated with NBCCS. ${ }^{35}$ Approximately $60 \%$ of patients have hypoplastic, fused, anteriorly splayed, or bifid ribs. ${ }^{35}$ Cervical ribs and spina bifida occulta of the cervical and thoracic vertebrae are also common. Lamellar calcification of the falx cerebri is a classical finding which appears early in life in approximately $85 \%$ of patients. ${ }^{35}$ Other areas of 
calcification include the tentorium cerebelli, meninges, choroid plexus, and diaphragma sellae. Calcification of the diaphragma sellae results in bridging of the sella turcica and is a common finding in NBCCS. ${ }^{35}$ Many patients have characteristic coarse facial features with frontal bossing, macrocephaly, mild mandibular prognathism, and ocular hypertelorism.

Patients with NBCCS are predisposed to tumours of the central nervous, cardiovascular, and genitourinary systems. ${ }^{35}$ Early onset medulloblastoma (average age two years), well documented within this syndrome, ${ }^{43}$ is the most common malignant brain tumour in childhood. Approximately 5\% of patients with NBCCS develop this tumour early in life. Medulloblastomas as a part of NBCCS have better outcomes than sporadic cases..$^{43}$ Other CNS tumours associated with NBCCS include meningiomas and craniopharyngiomas. ${ }^{35}$ Cardiac fibromas, which constitute $5 \%$ of primary cardiac neoplasms, are also associated with NBCCS. These rare benign tumours appear in some NBCCS patients, usually in the first decade, and behave similarly to their isolated counterparts. ${ }^{35}$ Common genitourinary tumours associated with NBCCS include bilateral calcified ovarian fibromas. ${ }^{35}$

\section{Genetics of NBCCS}

The susceptibility gene was mapped to $9 \mathrm{q} 22.3-\mathrm{q} 31$ by linkage analysis. ${ }^{44}$ Subsequently, the candidate gene was identified as the human homolog of the Drosophila patched gene and germline mutations were found in patients with NBCCS. ${ }^{45} 46$ Patched consists of 23 exons and encodes a 1500 amino acid transmembrane protein. Genetic studies in Drosophila show that patched is part of the hedgehog signalling pathway, important in determining embryonic patterning and cell fate in multiple structures of the developing embryo. ${ }^{37}$ While in Drosophila there is a single hedgehog molecule, in vertebrates three homologues known as Sonic, Desert, and Indian hedgehog, with Sonic hedgehog being the most widely expressed. The hedgehog signal is received and transduced at the membrane via a receptor complex consisting of patched and smoothened. In the absence of hedgehog binding, patched is thought to hold smoothened in an inactive state and thus inhibit signalling downstream genes. With the binding of hedgehog, patched inhibition of smoothened is released and the signal is transduced. ${ }^{47}$

Patched is a tumour suppressor gene mutated in hereditary BCCs (NBCCS). Screening of the patched coding region reveals a wide spectrum of germline mutations in NBCCS patients, with the majority predicted to result in premature protein truncations $(\sim 86 \%)$. Mutations are spread out the entire gene with no apparent clustering and a genotype-phenotype correlation does not appear to be present. ${ }^{48}$

Key components of the hedgehog pathway are implicated in tumour formation. In addition to BCCs (hereditary and sporadic), patched is mutated in medulloblastoma, meningioma, neuroectodermal tumour, breast carcinoma, oesophageal carcinoma, squamous cell carcinoma, and trichoepithelioma. ${ }^{47}$ Additionally, activating mutations in smoothened are identified in sporadic BCCs and medulloblastoma. ${ }^{47}$ Thus inactivation of patched or oncogenic activation of smoothened in the majority of BCCs suggests that deregulation of hedgehog signalling is a requirement for BCC formation. Of interest, rare mutations in patched2, which is a close homolog of patched (also referred as patchedl), have also been reported in medulloblastoma and sporadic BCCs. ${ }^{47}$

\section{GENERALISED BASALOID FOLLICULAR HAMARTOMA SYNDROME}

Generalised basaloid follicular hamartoma syndrome (GBFHS) (OMIM 605827) is an autosomal dominantly inherited disease characterised by the presence of basaloid follicular hamartomas in association with hypotrichosis (sparse hair). ${ }^{49}$

\section{Clinical features of GBFHS}

Basaloid follicular hamartomas are benign skin appendage tumours that show hair follicle differentiation. They are clinically indistinguishable from BCCs seen in NBCCS patients (fig 2A). The diagnosis of a basaloid follicular hamartoma by histopathological examination may at times be difficult. ${ }^{50}$ Thus the diagnosis of GBFHS and exclusion from NBCCS may require multiple biopsies and evaluation of systemic associations. The skin lesions present early in childhood as multiple small skin coloured papules. They are predominantly located on the central face, but may involve the scalp, neck, and trunk. The tumours steadily increase in size and number during childhood and adolescence and eventually become static in adulthood. ${ }^{50}$ In many cases, hundreds of lesions exist. GBFHS can be associated with milia, comedones, and acrochordons. Patients with GBFHS, as in NBCCS and Cowden syndrome, may also present with palmar pits. ${ }^{50}$ Unlike NBCCS, they lack odontogenic keratocysts, tissue calcification, skeletal abnormalities, and predisposition to internal tumours.

Basaloid follicular hamartomas can be solitary or multiple. Multiple lesions are observed in the inherited form, GBFHS. Multiple basaloid follicular hamartomas have also been observed in association with autoimmune disorders such as alopecia universalis, ${ }^{49}$ myasthenia gravis, ${ }^{49}$ systemic lupus erythematosus, ${ }^{51}$ and antiphospholipid antibody syndrome. ${ }^{52}$ Additional reports of GBFHS will help clarify whether the association of autoimmune diseases is coincidental or a part of the syndrome. Malignant transformation of the skin lesions to basal cell carcinomas has been reported. ${ }^{53}$ Although systemic malignancy is not an established feature of the syndrome, there is a case of GBFHS described in association with chondrosarcoma. ${ }^{54}$

\section{Genetics of GBFHS}

The gene locus of this dominantly inherited syndrome has yet to be determined. Of interest, GBFHS shares overlapping clinical and histopathological features with the autosomal dominantly inherited NBCCS. In NBCCS, constitutive activation of the hedgehog signalling owing to mutations in patched is believed to play a key role in tumorigenesis. To date, there is limited information on the molecular basis of basaloid follicular hamartomas. Recently, deregulation of the hedgehog signalling pathway has been implicated in the pathogenesis of basaloid follicular hamartomas. Transgenic mice expressing the human M2SMO mutant or Gli $_{2}$ develop lesions similar to human basaloid follicular hamartomas. ${ }^{55}$

\section{BAZEX SYNDROME}

Bazex syndrome (OMIM 301845), also known as BazexDupre-Christol syndrome, was described by Bazex in 1964. ${ }^{56}$ It is an X linked dominant disease characterised by early onset basal cell carcinomas associated with congenital hypotrichosis (sparse hair) and follicular atrophoderma (ice pick depressions on the skin). ${ }^{56}$

Follicular atrophoderma is most often observed on the dorsa of the hands and feet, on the face, and on the extensor surface of the elbows and knees. Hypotrichosis is a typical feature of the syndrome and is caused by hair shaft abnormalities such as pili torti and trichorrhexis nodosa. Basal cell carcinomas start to develop in the second or third decade. Vabres et al found evidence for X linkage and regional assignment to $\mathrm{Xq} 24-27^{57}$; however, the candidate gene remains to be identified. Bazex syndrome should not be confused with a clinically distinct syndrome reported by the same investigator and also known as Bazex syndrome or acrokeratosis paraneoplastica. This particular disease is not 
inherited and is characterised by psoriasiform skin findings and internal malignancy, most frequently squamous cell carcinoma of the upper aerodigestive tract.

\section{BROOKE-SPIEGLER SYNDROME, FAMILIAL CYLINDROMATOSIS, AND MULTIPLE FAMILIAL TRICHOEPITHELIOMA}

Brooke-Spiegler syndrome (BSS) (OMIM 605041), familial cylindromatosis (FC) (OMIM 132700), and multiple familial trichoepithelioma (MFT) (OMIM 601606), originally described as distinct entities, share overlapping clinical findings. Patients with BSS are predisposed to multiple skin appendage tumours such as cylindroma, trichoepithelioma, and spiradenoma. FC, however, is characterised by cylindromas and MFT by trichoepitheliomas as the only tumour type. All three conditions have recently been shown to be allelic.

\section{Clinical features of BSS, FC, and MFT}

The inherited occurrence of cylindromas and trichoepitheliomas was recognised in the mid-1800s; the conditions were termed Ancell-Spiegler cylindromas ${ }^{58} 59$ and Brooke-Fordyce trichoepitheliomas, ${ }^{60}{ }^{61}$ respectively. Subsequently, the combination of trichoepitheliomas and cylindromas in a series of patients was reported, suggesting the occurrence of these tumours within a single genetic entity.$^{62}$ In the 1970 s reports of spiradenomas coexisting with trichoepitheliomas and cylindromas began to appear, eventually establishing this triad of skin neoplasms in BSS. ${ }^{63}$ In addition to these tumours, BCCs ${ }^{64}$ and syringomas ${ }^{65}$ have been described in patients with BSS. As BCCs are common skin tumours, it is not clear whether their occurrence is coincidental or whether it is a manifestation of this syndrome.

The cutaneous lesions are primarily localised in the head and neck region. ${ }^{62}$ Cylindromas typically occur on the scalp, with less frequent involvement of the face, trunk, and extremities. Trichoepitheliomas show a predilection for the face (the nose, nasolabial folds, and upper lips (fig lB, lE)). These tumours appear early in adulthood and gradually increase in size and number throughout life; they may cause considerable disfigurement and discomfort. In BSS and FC patients, cylindromas can cover the entire scalp resulting in so called "turban tumours." Similarly, multiple trichoepitheliomas can cover the entire face. BSS tumours are clinically indistinguishable, so the gold standard for diagnosis is histopathological examination.

While cylindromas and spiradenomas arise from the sweat glands (apocrine or eccrine), trichoepitheliomas show hair follicle differentiation. These skin tumours can be sporadic or inherited. Solitary tumours typically occur sporadically, whereas multiple tumours are seen in patients with the inherited disorder (BSS, FC, or MFT). Although these are benign neoplasms malignant transformation have been reported. Over 25 cases of solitary and multiple cylindromas with malignant transformation into cylindrocarcinomas have been reported, and are more common in the multiple inherited BSS or FC type. ${ }^{66}$ In both solitary and multiple trichoepitheliomas there has been malignant transformation into BCC. ${ }^{67}$ BCC typically shows local infiltrative and destructive growth with a very low risk of metastasis. ${ }^{68}$ Similarly, over 35 cases of spiradenoma have been reported with carcinomatous or sarcomatous differentiation. ${ }^{69}$ However, both cylindrocarcinoma ${ }^{66}$ and malignant spiradenoma ${ }^{69}$ have been reported to result in local infiltrative growth and distant metastases leading to fatal outcome. In addition to tumours of skin appendages, BSS has also been infrequently associated with adenomas and adenocarcinomas of the salivary and parotid glands. ${ }^{70}$

\section{Genetics of BSS, FC, and MFT}

Linkage analysis in 16 families with multiple cylindromas (FC) mapped the susceptibility gene to a single locus on chromosome 16q12-q13. ${ }^{71}$ Subsequently, the CYLD gene was identified by positional cloning and germline mutations were discovered in affected families. ${ }^{72}$ Cylindromas showed LOH in 16q near the susceptibility gene, suggesting tumour suppressor function for CYLD. ${ }^{72}$

CYLD mutations are identified in patients with phenotypic features of BSS, FC, or MFT. ${ }^{73}$ Together with the observations that features of BSS, FC, and MFT can occur in the same patient or in different patients within a single family ${ }^{74}$ and that a single CYLD mutation can be associated with both cylindromas and trichoepitheliomas, ${ }^{75}$ this suggests that these syndromes not only share a common genetic basis but represent phenotypic variation of the same disease. The CYLD gene consists of 20 exons, of which the first three are untranslated. It encodes a 956 amino acid protein and an alternatively spliced product of 953 amino acids. ${ }^{72}$ The majority of reported CYLD mutations $(\sim 90 \%)$ are predicted to result in premature protein truncations. ${ }^{72}$ To date, no mutations in the N-terminal region of CYLD encoding the first two cytoskeletal associated protein glycine conserved motifs have been reported (exons 4-8), implicating the importance of these domains for its function. The mutations, however, are scattered throughout the mid-portion and Cterminal region. Although clustering of mutations in the $\mathrm{C}$ terminal region (exons $16-20)$ is noted $(\sim 60 \%)$, this is not limited to one particular domain.

CYLD interacts with several members of the NF- $\kappa B$ signalling pathway, such as TRAF-2 (tumour necrosis factor receptor associated factor-2), ${ }^{76}$ TRIP (TRAF interacting protein), ${ }^{77}$ and IKK $\gamma /$ NEMO (IKB kinase $\gamma$ ), ${ }^{78}$ and negatively regulates $\mathrm{NF}-\kappa \mathrm{B}$ activation. It also has enzymatic activity to deubiquitinate target proteins. ${ }^{78}$

The NF- $\kappa \mathrm{B} /$ Rel family of inducible transcription factors has key roles in inflammation, immune response, and oncogenesis. NF- $\kappa$ B suppression results in severe defects in the early steps of the development of epidermal appendages, including hair follicles and the sweat glands. ${ }^{79} \mathrm{NF}-\kappa \mathrm{B}$ activation is associated with neoplasms in a variety of tissues. However, the mechanism of aberrant NF- $\mathrm{BB}$ signalling and oncogenesis in the skin is not well understood. Various studies suggested a growth promoting role for NF- $\kappa \mathrm{B},{ }^{80}$ whereas others showed growth inhibition of NF- $\mathrm{BB}$ in epithelial tissues. ${ }^{81}$ The mechanisms of CYLD dependent tumorigenesis in the skin remain to be established.

\section{MUIR-TORRE SYNDROME}

Muir-Torre syndrome (MTS) (OMIM 158320) is an autosomal dominantly inherited disease described in 1967 and 1968, characterised by the presence of cutaneous sebaceous neoplasms in association with one or more low grade visceral malignancies. ${ }^{82}{ }^{83}$ Colorectal cancer is the most commonly observed visceral malignancy in MTS, followed by genitourinary cancers. ${ }^{84}$

\section{Clinical features of MTS}

MTS specific skin appendage tumours show sebaceous differentiation and include sebaceous adenomas, sebaceous epitheliomas, and sebaceous carcinomas.$^{85}$ In general, sebaceous tumours of the skin are rare and can occur sporadically or as a phenotypic expression of MTS. The association of one MTS specific sebaceous tumour with an internal malignancy is adequate to establish a diagnosis for MTS. ${ }^{85}$ These tumours present clinically as yellow papules or nodules, typically localised on the head and neck (fig 2E, 2F). They can be solitary or multiple. The sebaceous tumours in MTS can precede, occur concurrently, or follow the diagnosis of 
internal malignancy. ${ }^{85}$ As a result, incomplete clinical presentations can be seen before a definite diagnosis of MTS is established. The complete clinical presentation can be observed as early as the fourth decade; but most patients are in their sixth decade at the time of diagnosis.

Although sebaceous adenomas are the most distinctive cutaneous marker for MTS, other MTS specific sebaceous neoplasms such as sebaceous epithelioma and carcinoma are nearly as specific. ${ }^{85}$ Sebaceous carcinoma, however, can also be seen in association with immunosuppression after organ transplantation $^{8687}$ or with AIDS. ${ }^{85}$ It is unclear whether immunosuppression unmasks the expression of a latent MTS phenotype or selects the emergence of a mutator phenotype (accumulation of replication errors leading to genetically instability) and thus predispose individuals to the development of sebaceous carcinomas. ${ }^{86}$ There are sebaceous tumours of the skin that are not specific to MTS such as sebaceous hyperplasia and nevus sebaceous of Jadassohn. ${ }^{85}$ Another type of skin tumour that is not specific to MTS but can be often seen in this syndrome is keratoacanthoma, which can be solitary or multiple. ${ }^{85}$ This tumour arises from the epidermal keratinocytes and may occasionally show sebaceous differentiation.

Patients with MTS are predisposed to developing internal malignancies. The majority consist of colorectal carcinoma $(\sim 50 \%)$ followed by genitourinary cancers $(\sim 25 \%) .{ }^{85}$ In contrast to its presentation in the general population, colorectal cancer in MTS occurs predominantly proximal to the splenic flexure and is usually detected a decade earlier. Interestingly, despite predisposing affected patients to multiple visceral malignancies, the sebaceous and visceral cancers of MTS are less aggressive than their non-MTS counterparts. ${ }^{85}$ As a result, MTS responds well to aggressive surgical management, affording a relatively favourable prognosis with prolonged survival even in the presence of metastases.

\section{Genetics of MTS}

There are two well studied familial colorectal carcinoma syndromes, hereditary non-polyposis colorectal cancer syndrome (HNPCC, also known as Lynch syndrome) (OMIM 114400 ) and familial adenomatous polyposis (OMIM 175100). Together these account for approximately 5\% of colorectal carcinomas. The spectrum of internal cancers in MTS is identical to that of the HNPCC ${ }^{88}$ It is caused by germline mutations in DNA mismatch repair genes. ${ }^{89-91}$ The DNA mismatch repair system is critical for the maintenance of genomic stability. It increases the fidelity of single base mismatches and insertion-deletion loops that may arise during DNA replication. Thus this system serves a DNA damage surveillance function by preventing incorrect base pairing or avoiding insertion-deletion loops by slippage of DNA polymerase. ${ }^{92}$ Consequently, mismatch repair deficiency results in accumulating mutations of these microsatellites, which is termed microsatellite instability. ${ }^{93}$ Mismatch repair genes behave like tumour suppressors, in that cancer arises in individuals who are heterozygous for mutations when the wild type allele is knocked out somatically in a target cell, such as in the colonic epithelium. The second hit can occur by deletion, mutation, or methylation of $\mathrm{CpG}$ islands in the promoter.

Various DNA mismatch repair genes (MLH1, MSH2, PMS1, PMS2, MSH3, and MSH6) have been associated with HNPCC. ${ }^{93}$ However, two of these genes (MLHl and MSH2) are responsible for the majority of mutation positive HNPCC cases. Genetic evidence that MTS could represent a phenotypic variant of HNPCC was discovered in 1994. Subsequently, germline mutations in MSH2 and later in MLHI were identified in families with MTS, further indicating that MTS is an expression variant of HNPCC. ${ }^{93}$ Moreover,
MSH2-/- and MLH-/- knockout mice also develop sebaceous skin tumours in addition to internal malignancies. ${ }^{94}$ Mutations in MSH2 are more often observed than MLHl in patients with MTS. The vast majority of these mutations are truncating mutations that lead to a dysfunctional mismatch repair protein and are distributed over the entire gene with no evidence of a mutational hotspot.95 Besides the strong genoype-phenotype correlation between MSH2 and MTS, there is little evidence indicating other genotype-phenotype correlations in hereditary mismatch repair defects.

\section{CONCLUSIONS}

Over the past decade significant progress in understanding the molecular basis of skin appendage tumours has been made. It is crucial to emphasise that the skin neoplasms are pathognomonic findings for the genodermatoses described in this review. As every clinical sign enabling the detection of a hereditary predisposition to visceral cancer will be of great value for general cancer prevention, knowledge of these recent molecular advances in inherited skin appendage tumour syndromes is essential. By careful skin examination, a significant proportion of patients with hereditary cancer predisposition can be identified. In principle, these patients should be offered molecular genetic diagnosis, and if necessary, a strict regular cancer surveillance programme.

\section{ACKNOWLEDGEMENTS}

We thank David N Silvers MD for reviewing the manuscript. We are grateful to the patients and families for their participation. This work was supported in part by the NIH/NIAMS (K08 AR050273) (JTC) and the Dermatology Foundation (JTC).

\section{Authors' affiliations}

D A Lee, M E Grossman, P Schneiderman, J T Celebi, Department of Dermatology, Columbia University Medical Center, New York, USA

Competing interests: none declared

\section{REFERENCES}

1 Fuchs $E$, Raghavan S. Getting under the skin of epidermal morphogenesis. Nat Rev Genet 2002;3:199-209.

2 Eng C. Will the real Cowden syndrome please stand up? Revised diagnostic criteria. J Med Genet 2000;37:828-30.

3 Starink TM, van der Veen JP, Arwert F, de Waal LP, de Lange GG, Gille JJ, Eriksson AW. The Cowden syndrome: a clinical and genetic study in 21 patients. Clin Genet 1986;29:222-33.

4 Starink TM, Hausman R. The cutaneous pathology of facial lesions in Cowden's disease. J Cutan Pathol 1984;11:331-7.

5 Pilarski R, Eng C. Will the real Cowden syndrome please stand up (again)? Expanding mutational and clinical spectra of the PTEN hamartoma tumour syndrome. J Med Genet 2004:41:323-26.

6 Brownstein MH, Wolf M, Bikowski JB. Cowden's disease: a cutaneous marker of breast cancer. Cancer 1978;41:2393-8.

7 Schrager CA, Schneider D, Gruener AC, Tsou HC, Peacocke M. Clinical and pathological features of breast disease in Cowden's syndrome: an underrecognized syndrome with an increased risk of breast cancer. Hum Pathol 1998;29:47-53.

8 Padberg GW, Schot JD, Vielvoye GJ, Bots GT, de Beer FC. Lhermitte-Duclos disease and Cowden disease: a single phakomatosis. Ann Neurol 1991;29:517-23.

9 Eng C, Murday V, Seal S, Mohammed S, Hodgson SV, Chaudary MA, Fentiman IS, Ponder BA, Eeles RA. Cowden syndrome and Lhermitte-Duclos disease in a family: a single genetic syndrome with pleiotropy? J Med Genet 1994:31:458-61.

10 Nelen MR, Padberg GW, Peeters EA, Lin AY, van den Helm B, Frants RR, Coulon V, Goldstein AM, van Reen MM, Easton DF, Eeles RA, Hodgsen S, Mulvihill jJ, Murday VA, Tucker MA, Mariman EC, Starink TM, Ponder BA, Ropers $\mathrm{HH}$, Kremer $\mathrm{H}$, Longy $\mathrm{M}$, Eng $\mathrm{C}$. Localization of the gene for Cowden disease to chromosome 10q22-23. Nat Genet 1996;13:114-16.

11 Steck PA, Pershouse MA, Jasser SA, Yung WK, Lin H, Ligon AH, Langford LA, Baumgard ML, Hattier T, Davis T, Frye C, Hu R, Swedlund B, Teng DH, Tavtigian SV. Identification of a candidate tumour suppressor gene, MMACl, at chromosome $10 \mathrm{q} 23.3$ that is mutated in multiple advanced cancers. Nat Genet 1997; 15:356-62.

12 Liaw D, Marsh DJ, Li J, Dahia PL, Wang SI, Zheng Z, Bose S, Call KM, Tsou HC, Peacocke M, Eng C, Parsons R. Germline mutations of the PTEN 
gene in Cowden disease, an inherited breast and thyroid cancer syndrome. Nat Genet 1997;16:64-7.

13 Li J, Yen C, Liaw D, Podsypanina K, Bose S, Wang SI, Puc J, Miliaresis C, Rodgers L, McCombie R, Bigner SH, Giovanella BC, Ittmann M, Tycko B, Hibshoosh $\mathrm{H}$, Wigler $\mathrm{MH}$, Parsons R. PTEN, a putative protein tyrosine phosphatase gene mutated in human brain, breast, and prostate cancer. Science 1997; 275: 1943-7.

14 Waite KA, Eng C. Protean PTEN: form and function. Am J Hum Genet 2002:70:829-44.

15 Marsh DJ, Coulon V, Lunetta KL, Rocca-Serra P, Dahia PL, Zheng Z, Liaw D, Caron S, Dubove B, Lin AY, Richardson AL, Bonnetblanc JM, Bressieux JM, Cabarrot-Moreau A, Chompret A, Demange L, Eeles RA, Yahanda AM, Fearon ER, Fricker JP, Gorlin RJ, Hodgson SV, Huson S, Lacombe D, Eng C, et al. Mutation spectrum and genotype-phenotype analyses in Cowden disease and Bannayan-Zonana syndrome, two hamartoma syndromes with germline PTEN mutation. Hum Mol Genet 1998;7:507-15.

16 Marsh DJ, Kum JB, Lunetta KL, Bennett MJ, Gorlin RJ, Ahmed SF, Bodurtha J, Crowe C, Curtis MA, Dasouki M, Dunn T, Feit H, Geraghty MT, Graham JM, Hodgson SV, Hunter A, Korf BR, Manchester D, Miesfeldt S, Murday VA, Nathanson KL, Parisi M, Pober B, Romano C, Eng C, et al. PTEN mutation spectrum and genotype-phenotype correlations in Bannayan-RileyRuvalcaba syndrome suggest a single entity with Cowden syndrome. Hum Mol Genet 1999:8:1461-72.

17 Celebi JT, Tsou HC, Chen FF, Zhang H, Ping XL, Lebwohl MG, Kezis J, Peacocke M. Phenotypic findings of Cowden syndrome and BannayanZonana syndrome in a family associated with a single germline mutation in PTEN. J Med Genet 1999:36:360-4.

18 Zhou X-P, Hampel H, Thiele H, Gorlin RJ, Hennekam RCM, Parisi M, Winter RM, Eng C. Association of germline mutation in the PTEN tumour suppressor gene and Proteus and Proteus-like syndromes. Lancet 2001;358:210-11.

19 Birt AR, Hogg GR, Dube WJ. Hereditary multiple fibrofolliculomas with trichodiscomas and acrochordons. Arch Dermatol 1977;113:1674-7.

20 Pinkus H, Coskey R, Burgess GH. Trichodiscoma. A benign tumor related to haarscheibe (hair disk). J Invest Dermatol 1974;63:212-18.

21 Collins GL, Somach S, Morgan MB. Histomorphologic and immunophenotypic analysis of fibrofolliculomas and trichodiscomas in Birt-Hogg-Dube syndrome and sporadic disease. J Cutan Pathol 2002;29:529-33.

22 De la Torre C, Ocampo C, Doval IG, Losada A, Cruces MJ. Acrochordons are not a component of the Birt-Hogg-Dube syndrome: does this syndrome exist? Case reports and review of the literature. [see comment]. Am J Dermatopathol 1999;21:369-74.

23 Roth JS, Rabinowitz AD, Benson M, Grossman ME. Bilateral renal cell carcinoma in the Birt-Hogg-Dube syndrome. J Am Acad Dermatol 1993;29:1055-56.

24 Zbar B, Alvord WG, Glenn G, Turner M, Pavlovich CP, Schmidt L, Walther M Choyke P, Weirich G, Hewitt SM, Duray P, Gabril F, Greenberg C, Merino MJ Toro J, Linehan WM. Risk of renal and colonic neoplasms and spontaneous pneumothorax in the Birt-Hogg-Dube syndrome. Cancer Epidemiol Biomarkers Prev 2002;11:393-400.

25 Chung JY, Ramos-Caro FA, Beers B, Ford MJ, Flowers F. Multiple lipomas, angiolipomas, and parathyroid adenomas in a patient with Birt-Hogg-Dube syndrome. Int J Dermatol 1996;35:365-67.

26 Liv V, Kwan T, Page EH. Parotid oncocytoma in the Birt-Hogg-Dube syndrome. J Am Acad Dermatol 2000;43:1 120-22.

27 Vincent A, Farley M, Chan E, James WD. Birt-Hogg-Dube syndrome: two patients with neural tissue tumors. J Am Acad Dermatol 2003;49:717-19.

28 Toro JR, Glenn G, Duray P, Darling T, Weirich G, Zbar B, Linehan M, Turner ML. Birt-Hogg-Dube syndrome: a novel marker of kidney neoplasia. Arch Dermatol 1999:135:1195-202.

29 Khoo SK, Giraud S, Kahnoski K, Chen J, Motorna O, Nickolov R, Binet O, Lambert D, Friedel J, Levy R, Ferlicot S, Wolkenstein P, Hammel P, Bergerheim U, Hedblad MA, Bradley M, Teh BT, Nordenskiold M, Richard S. Clinical and genetic studies of Birt-Hogg-Dube syndrome. J Med Genet 2002;39:906-12.

30 Kahnoski K, Khoo SK, Nassif NT, Chen J, Lobo GP, Segelov E, Teh BT. Alterations of the Birt-Hogg-Dube gene (BHD) in sporadic colorectal tumours. $J$ Med Genet 2003;40:511-15.

31 Shin J-H, Shin Y-K, Ku J-L, Jeong S-Y, Hong S-H, Park S-Y, Kim WH, Park JG Mutations of the Birt-Hogg-Dube (BHD) gene in sporadic colorectal carcinomas and colorectal carcinoma cell lines with microsatellite instability. J Med Genet 2003;40:364-7.

32 Khoo SK, Bradley M, Wong FK, Hedblad MA, Nordenskjold M, Teh BT. BirtHogg-Dube syndrome: mapping of a novel hereditary neoplasia gene to chromosome 17p12-q1 1.2. Oncogene 2001;20:5239-42.

33 Schmidr LS, Warren MB, Nickerson ML, Weirich G, Matrosova V, Toro JR, Turner ML, Duray P, Merino M, Hewitt S, Pavlovich CP, Glenn G, Greenberg CR, Linehan WM, Zbar B. Birt-Hogg-Dube syndrome, a genodermatosis associated with spontaneous pneumothorax and kidney neoplasia, maps to chromosome 17p1 1.2. Am J Hum Genet 2001;69:876-82.

34 Nickerson ML, Warren MB, Toro JR, Matrosova V, Glenn G, Turner ML, Duray P, Merino M, Choyke P, Pavlovich CP, Sharma N, Walther M Munroe D, Hill R, Maher E, Greenberg C, Lerman MI, Linehan WM, Zbar B, Schmidt LS. Mutations in a novel gene lead to kidney fumors, lung wall defects, and benign tumors of the hair follicle in patients with the Birt-Hogg-Dube syndrome. Cancer Cell 2002;2:157-64.

35 Gorlin RJ, Goltz RW. Multiple nevoid basal-cell epithelioma, jaw cysts and bifid rib. A syndrome. N Engl J Med 1960;262:908-12.

36 Gorlin RJ. Nevoid basal-cell carcinoma syndrome. Medicine (Baltimore) 1987:66:98-113.
37 Bale AE, Yu KP. The hedgehog pathway and basal cell carcinomas. Hum Mol Genet 2001;10:757-62.

38 Southwick GJ, Schwartz RA. The basal cell nevus syndrome: disasters occurring among a series of 36 patients. Cancer 1979:44:2294-305.

39 Murphy KJ. Metastatic basal cell carcinoma with squamous appearances in the naevoid basal cell carcinoma syndrome. Br J Plast Surg 1975;28:331-4.

40 Winkler PA, Guyuron B. Multiple metastases from basal cell naevus syndrome. Br J Plast Surg 1987;40:528-31.

41 Taylor WB, Wilkins JW. Nevoid basal cell carcinoma of the palm. Arch Dermatol 1970;102:654-5.

42 Leppard BJ. Skin cysts in the basal cell naevus syndrome. Clin Exp Dermatol 1983:8:603-12.

43 Amlashi SF, Riffaud L, Brassier G, Morandi X. Nevoid basal cell carcinoma syndrome: relation with desmoplastic medulloblastoma in infancy. A population-based study and review of the literature. Cancer 2003:98:618-24.

44 Farndon PA, Del Mastro RG, Evans DG, Kilpatrick MW. Location of gene for Gorlin syndrome. Lancet 1992;339:581-2.

45 Johnson RL, Rothman AL, Xie J, Goodrich LV, Bare JW, Bonifas JM, Quinn AG, Myers RM, Cox DR, Epstein EH, Scott MP. Human homolog of patched, a candidate gene for the basal cell nevus syndrome. Science 1996;272:1668-71

46 Hahn H, Wicking C, Zaphiropoulous PG, Gailani MR, Shanley S, Chidambaram A, Vorechovsky I, Holmberg E, Unden AB, Gillies S, Negus K, Smyth I, Pressman C, Leffell DJ, Gerrard B, Goldstein AM, Dean M, Toftgard R, Chenevix-Trench G, Wainwright B, Bale AE. Mutations of the human homolog of Drosophila patched in the nevoid basal cell carcinoma syndrome. Cell 1996;85:841-51.

47 Cohen MM. The hedgehog signaling network. Am J Med Genet A 2003;123:5-28.

48 Wicking C, Shanley S, Smyth I, Gillies S, Negus K, Graham S, Suthers G, Haites N, Edwards M, Wainwright B, Chenevix-Trench G. Most germ-line mutations in the nevoid basal cell carcinoma syndrome lead to a premature termination of the PATCHED protein, and no genotype-phenotype correlations are evident. Am J Hum Genet 1997;60:21-6.

49 Brown AC, Crounse RG, Winkelmann RK. Generalized hair-follicle hamartoma, associated with alopecia, aminoacidura, and myasthenia gravis. Arch Dermatol 1969;99:478-93

50 Wheeler CE, Carroll MA, Groben PA, Briggaman RA, Prose NS, Davis DA Autosomal dominantly inherited generalized basaloid follicular hamartoma syndrome: report of a new disease in a North Carolina family [see comment]. J Am Acad Dermatol 2000;43:189-206.

51 Akasaka T, Kon S, Mihm MC. Multiple basaloid cell hamartoma with alopecia and autoimmune disease (systemic lupus erythematosus). J Dermatol 1996;23:821-4.

52 Morton S, Stevens A, Powell RJ. Basaloid follicular hamartoma, total body hair loss and SLE. Lupus 1998;7:207-9.

53 Jih DM, Shapiro M, James WD, Levin M, Gelfand J, Williams PT, Oakey RJ, Fakharzadeh S, Seykora JT. Familial basaloid follicular hamartoma: lesional characterization and review of the literature. Am J Dermatopathol 2003;25:130-7.

54 Ricks M, Elston DM, Sartori CR. Multiple basaloid follicular hamartomas associated with acrochordons, seborrhoeic keratoses and chondrosarcoma. Br J Dermatol 2002;146:1068-70.

55 Grachtchouk V, Grachtchouk M, Lowe L, Johnson T, Wei L, Wang A, de Sauvage F, Dlugosz AA. The magnitude of hedgehog signaling activity defines skin tumor phenotype. Embo J 2003;22:2741-51.

56 Glaessl A, Hohenlautner U, Landthaler M, Vogt T. Sporadic Bazex-DupreChristol-like syndrome: early onset basal cell carcinoma, hypohidrosis, hypotrichosis, and prominent milia. Dermatol Surg 2000;26:152-4.

57 Vabres P, Lacombe D, Rabinowitz LG, Aubert G, Anderson CE, Taieb A Bonafe JL, Hors-Cayla MC. The gene for Bazex-Dupre-Christol syndrome maps to chromosome Xq. J Invest Dermatol 1995; 105:87-91.

58 Ancell $\mathbf{H}$. History of a remarkable case of tumours developed on the head and face; accompanied with a similar disease in the abdomen. Med Chir Trans 1842;25:227-46.

59 Spiegler E. Ueber Endoteliome der Haut. AMA Arch Dermatol Syphilis 1899;50:163-76

60 Brooke H. Epithelioma adenoides cysticum. Br J Dermatol Syphilis 1892;4:286-96.

61 Fordyce J. Multiple benign cystic epithelioma of the skin. J Cutan Dis 1892;10:459-73

62 Welch J, Wells R, Kerr C. Ancell-Spiegler Cylindromas (turban tumors) and Brooke-Fordyce Trichoepitheliomas: evidence for a single genetic entity. J Med Genet 1968;5:29-35

63 Gottschalk HR. Proceedings: dermal eccrine cylindroma, epithelioma adenoides cysticum of Brooke, and eccrine spiradenoma. Arch Dermatol 1974:110:473-4.

64 Carsuzaa F, Carloz E, Lebeuf M, Grob JJ, Arnoux D. [Multiple trichoepithelioma, cylindroma, miliaria and carcinomatous transformation. ] Ann Dermatol Venereol, 1992;119:746-8.

65 Uede K, Yamamoto Y, Furukawa F. Brooke-Spiegler syndrome associated with cylindroma, trichoepithelioma, spiradenoma, and syringoma. J Dermatol 2004;31:32-8

66 Gerretsen A, van der Putte S, Deenstra W. Cutaneous cylindroma with malignant transformation. Cancer 1993;72:1618-23.

67 Ayhan M, Adanali G, Senen D, Gorgu M, Erdogan B. Rarely seen cutaneous lesions in an elderly patient: malignant transformation of multiple trichoepithelioma. Ann Plast Surg 2001;47:98-9. 
68 Lo JS, Snow SN, Reizner GT, Mohs FE, Larson PO, Hruza GJ. Metastatic basal cell carcinoma: report of twelve cases with a review of the literature [see comment]. J Am Acad Dermatol 1991;24:715-19.

69 Ishikawa M, Nakanishi Y, Yamazaki N, Yamamoto A. Malignant eccrine spiradenoma: a case report and review of the literature [see comment]. Dermatol Surg 2001;27:67-70.

70 Jungehulsing $M$, Wagner $M$, Damm $M$. Turban fumour with involvement of the parotid gland. J Laryngol Otol 1999;1 13:779-83

71 Biggs PJ, Wooster R, Ford D, Chapman P, Mangion J, Quirk Y, Easton DF Burn J, Stratton MR. Familial cylindromatosis (turban tumour syndrome) gene localised to chromosome 16q12-q13: evidence for its role as a tumour suppressor gene. Nat Genet 1995;11:441-3.

72 Bignell GR, Warren W, Seal S, Takahashi M, Rapley E, Barfoot R, Green H, Brown C, Biggs PJ, Lakhani SR, Jones C, Hansen J, Blair E, Hofmann B, Siebert R, Turner G, Evans DG, Schrander-Stumpel C, Beemer FA, van Den Ouweland A, Halley D, Delpech B, Cleveland MG, Leigh I, Leisti J,

Rasmussen $\mathrm{S}$. Identification of the familial cylindromatosis tumour-suppressor gene. Nat Genet 2000;25:160-5

73 Hu G, Onder M, Gill M, Aksakal B, Oztas M, Gurer MA, Celebi JT. A novel missense mutation in CYLD in a family with Brooke-Spiegler syndrome. J Invest Dermatol 2003;121:732-4.

74 Gerretsen AL, Beemer FA, Deenstra W, Hennekam FA, van Vloten WA. Familial cutaneous cylindromas: investigations in five generations of a family. J Am Acad Dermatol 1995;33:199-206.

75 Poblete Gutierrez P, Eggermann T, Holler D, Jugert FK, Beermann T, Grussendorf-Conen El, Zerres K, Merk HF, Frank J. Phenotype diversity in familial cylindromatosis: a frameshift mutation in the tumor suppressor gene CYLD underlies different tumors of skin appendages. J Invest Dermatol 2002;119:527-31.

76 Brummelkamp TR, Niiman SM, Dirac AM, Bernards R. Loss of the cylindromatosis tumour suppressor inhibits apoptosis by activating NFkappaB [see comment]. Nature 2003;424:797-801.

77 Regamey A, Hohl D, Liu JW, Roger T, Kogerman P, Toftgard R, Huber M. The tumor suppressor CYLD interacts with TRIP and regulates negatively nuclear factor kappaB activation by tumor necrosis factor. J Exp Med 2003; 198:1959-64.

78 Trompouki E, Hatzivassiliou E, Tsichritzis T, Farmer H, Ashworth A, Mosialos G. CYLD is a deubiquitinating enzyme that negatively regulates NFkappaB activation by TNFR family members [see comment]. Nature 2003;424:793-6.

79 Schmidt-Ullrich R, Aebischer T, Hulsken J, Birchmeier W, Klemm U, Scheidereit C. Requirement of NF-kappaB/Rel for the development of hair follicles and other epidermal appendices. Development 2001;128:3843-53.
80 Seitz CS, Deng H, Hinata K, Lin Q, Khavari PA. Nuclear factor kappaB subunits induce epithelial cell growth arrest. Cancer Res 2000;60:4085-92. 81 Dajee M, Lazarov M, Zhang JY, Cai T, Green CL, Russell AJ, Marinkovich MP, Tao S, Lin Q, Kubo Y, Khavari PA. NF-kappaB blockade and oncogenic Ras trigger invasive human epidermal neoplasia. Nature 2003:421:639-43.

82 Muir EG, Bell AJ, Barlow KA. Multiple primary carcinomata of the colon, duodenum, and larynx associated with kerato-acanthomata of the face. $\mathrm{Br} J$ Surg 1967;54:191-5.

83 Torre D. Multiple sebaceous tumors. Arch Dermatol 1968;98:549-51.

84 Bitran J, Pellettiere EV. Multiple sebaceous gland tumors and internal carcinoma: Torre's syndrome. Cancer 1974;33:835-6.

85 Schwartz RA, Torre DP. The Muir-Torre syndrome: a 25 -year retrospect. J Am Acad Dermatol 1995;33:90-104.

86 Harwood CA, Swale VJ, Bataille VA, Quinn AG, Ghali L, Patel SV, DoveEdwin I, Cerio R, McGregor JM. An association between sebaceous carcinoma and microsatellite instability in immunosuppressed organ transplant recipients. J Invest Dermatol 2001;116:246-53.

87 Bordea C, Wojnarowska F, Millard PR, Doll H, Welsh K, Morris PJ. Skin cancers in renal-transplant recipients occur more frequently than previously recognized in a temperate climate. Transplantation 2004;77:574-9.

88 Lynch HT, Fusaro RM, Roberts L, Voorhees GJ, Lynch JF. Muir-Torre syndrome in several members of a family with a variant of the Cancer Family Syndrome. Br J Dermatol 1985;113:295-301.

89 Kruse R, Rutten A, Lamberti C, Hosseiny-Malayeri HR, Wang Y, Ruelfs $C$, Jungck M, Mathiak M, Ruzicka T, Hartschuh W, Bisceglia M, Friedl W, Propping P. Muir-Torre phenotype has a frequency of DNA mismatch-repairgene mutations similar to that in hereditary nonpolyposis colorectal cancer families defined by the Amsterdam criteria. Am J Hum Genet 1998:63:63-70.

90 Bapat B, Xia L, Madlensky L, Mitri A, Tonin P, Narod SA, Gallinger S. The genetic basis of Muir-Torre syndrome includes the hMLH1 locus. Am J Hum Genet 1996;59:736-9.

91 Kolodner RD, Hall NR, Lipford J, Kane MF, Rao MR, Morrison P, Wirth L, Finan PJ, Burn J, Chapman P. Structure of the human MSH2 locus and analysis of two Muir-Torre kindreds for msh2 mutations. Genomics 1994;24:516-26.

92 Narayan S, Roy D. Role of APC and DNA mismatch repair genes in the development of colorectal cancers. Mol Cancer 2003;2:41.

93 Entius MM, Keller JJ, Drillenburg P, Kuypers KC, Giardiello FM, Offerhaus GJ. Microsatellite instability and expression of hMLH-1 and hMSH-2 in sebaceous gland carcinomas as markers for Muir-Torre syndrome. Clin Cancer Res 2000;6:1784-9.

94 Wei K, Kucherlapati R, Edelmann W. Mouse models for human DNA mismatch-repair gene defects. Trends Mol Med 2002:8:346-53.

95 Kruse R, Ruzicka T. DNA mismatch repair and the significance of a sebaceous skin tumor for visceral cancer prevention. Trends Mol Med 2004; 10:136-41.

\section{bmjupdates+}

bmjupdates+ is a unique and free alerting service, designed to keep you up to date with the medical literature that is truly important to your practice.

bmjupdates+ will alert you to important new research and will provide you with the best new evidence concerning important advances in health care, tailored to your medical interests and time demands.

Where does the information come from?

bmjupdates+ applies an expert critical appraisal filter to over 100 top medical journals A panel of over 2000 physicians find the few 'must read' studies for each area of clinical interest

Sign up to receive your tailored email alerts, searching access and more...

www.bmjupdates.com 